\title{
Manajemen Komunikasi Bencana Pemerintah Desa Dalam Penanganan Covid-19
}

\author{
Muhammad Arif ${ }^{1}$, Suci Shinta Lestari ${ }^{2}$ \\ Universitas Abdurrab Pekanbaru \\ Email: muhammad.arif@univrab.ac.id
}

\begin{abstract}
The complexity of the Covid-19 disaster problem requires a mature communication arrangement or management in an effort to handle it, so that it can be carried out in a directed and integrated manner. The purpose of the study is to explain how disaster communication management is carried out by the village government in handling Covid-19. The method used in this research is descriptive qualitative. The sampling technique used was purposive sampling, while the data collection technique used in-depth interview and observation techniques. The results of this study indicate the importance of coordination and communication between parties related to disaster communication management. Through an alternative model approach to disaster communication management which includes aspects of planning, organizing, implementing and evaluating. Good relationship between both the village government and community members, can create effective disaster communication management so that disaster risks that may arise can be reduced or even avoided.
\end{abstract}

Keywords: Management, Disaster Communication, Covid-19

Abstrak: Kompleksitas dari permasalahan bencana Covid-19 memerlukan suatu penataan atau manajemen komunikasi yang matang dalam upaya penanganannya, sehingga dapat dilaksanakan secara terarah dan terpadu. Tujuan penelitian adalah menjelaskan bagaimana manjemen komunikasi bencana yang dilakukan oleh pemerintah desa dalam penanganan Covid-19. Metode yang digunakan dalam penelitian ini adalah deskriptif kualitatif. Teknik penentuan sampel yang dengan menggunakan purposive sampling, sedangkan teknik pengambilan data menggunakan teknik wawancara mendalam (indepth interview) dan obesrvasi. Hasil dari penelitian ini menunjukkan pentingnya koordinasi dan komunikasi antar pihak terkait manajemen komunikasi bencana. Melalui pendekatan model alternatif manajemen komunikasi bencana meliputi aspek perencanaan, pengorganisasian, pelaksanaan dan evaluasi. Hubungan baik antara pemerintah desa dan warga masyarakat, dapat menciptakan manajemen komunikasi bencana yang efektif sehingga resiko bencana yang mungkin muncul dapat dikurangi bahkan dihindari.

Kata kunci: Manajemen, Komunikasi Bencana, Covid-19

\section{Pendahuluan}

Kata bencana seolah-olah menjadi akrab ditelinga kita, baik bencana alam, non alam maupun bencana sosial. Berbagai bencana tersebut memerlukan penanganan yang cepat dan tepat sasaran agar dapat mengurangi resiko kerugian baik jiwa maupun materi. Pengelolaan bencana bukan hanya menjadi tanggungjawab pemerintah semata, namun masyarakat juga memiliki tanggung jawab yang sama dalam penanggulangan dan pencegahan resiko bencana, baik pra, saat maupun pasca bencana melanda.

Dalam Undang-Undang Nomor 24 Tahun 2007 tentang penanggulangan bencana, dijelaskan bahwa "bencana adalah peristiwa atau rangaian peristiwa yang mengancam dan 
mengganggu kehidupan dan penghidupan masyarakat, yang disebabkan faktor alam dan/atau non-alam maupun faktor manusia, sehingga mengakibatkan timbulnya korban jiwa manusia, kerusakan lingkungan, kerugian harta benda, dan dampak psikologis (Santoso, 2011).

Berpijak kepada pengertian bencana dari aspek legal, maka penanganan bencana sesungguhnya bukan semata - mata mengandalakan kemampuan untuk memberikan bantuan material saja, tetapi memberikan dukungan moral, kepada mereka yang terkena bencana, menjadi suatu keharusan. Melalui komunikasi yang berpedoman kepada etika dan substansi komunikasi dalam penyampaian pesan, dari satu sumber kepada sumber lain yang bertujuan memperoleh 3 pemahaman ataupun pemaknaan bersama, maka komunikasi menjadi sangat esensial dalam memberikan bantuan terhadap bencana alam. Namun tidak mudah untuk mengorganisasikan pesan - pesan bencana yang integratif dengan pemahaman bersama dari lembaga pemerintah, swasta dan masyarakat pada umumnya. Sebab secara faktual, ada pesan -pesan yang direduksi atau ditambahkan oleh mereka yang berkepentingan dalam karut marut penanganan bencana. Bukan rahasia lagi, problem koordinasi sebagaimana dalam uraian tugas lembaga sub - ordinat kekuasaan negara, masih dibelenggu oleh lemahnya komunikasi antar unit akibat menjalankan birokrasi yang teramat kaku (Santoso, 2011)

Salah satu bentuk bencana non-alam yang melanda dunia saat ini termasuk Indonesia adalah wabah virus Corona. Virus Corona adalah virus yang menyerang sistem pernapasan. Pernyakit akibat serangan virus ini terkenal dengan nama Covid -19. Severe acute respiratory syndrome coronavirus 2 (SARS-CoV-2) yang lebih dikenal dengan nama virus Corona adalah jenis baru dari coronavirus yang menular ke manusia. Virus ini bisa menyerang siapa saja, baik bayi, anak-anak, orang dewasa, lansia, ibu hamil, maupun ibu menyusui (https://kemlu.go.id/kabul/id/news/5980/, 2020). Pandemi Covid-19 yang melanda dunia sejak akhir 2019 telah memberikan pembelajaran berharga, karena dampaknya yang sangat besar pada seluruh sendi kehidupan masyarakat. Mengingat pandemi ini belum pernah terjadi sebelumnya, masyarakat sangat membutuhkan informasi yang tepat dan akurat, karena merekalah yang menghadapi pandemi ini dan merasakan dampaknya secara langsung.

Masyarakat selalu menjadi korban ketika ancaman krisis kesehatan terjadi. Oleh karena itu, upaya meningkatkan pengetahuan dan pemahaman masyarakat perlu dilakukan, agar mereka bisa berdaya dan memilih dengan benar tindakan pencegahan maupun penanganan seperti apa yang harus dilakukan. Upaya itu termasuk menyiapkan dan mengembangkan komunikasi bencana baik sebelum, pada saat, maupun sesudah terjadi ancaman.

Jumlah kasus positif Covid-19 di Indonesia yang terus meningkat menunjukkan bahwa pandemi masih terjadi. Berbagai upaya telah dilakukan, namun sebagian upaya tersebut belum berhasil dalam mengendalikan pandemi ini. Beredarnya berita palsu (hoax) dan tak selarasnya kebijakan pemerintah dalam menangani pandemi Covid-19 menimbulkan kebingungan masyarakat dalam menyikapi situasi pandemi. Sebagai akibatnya, persepsi masyarakat terhadap risiko penularan Covid-19 berubah-ubah sehingga memicu munculnya rasa aman semu (Fillaili dan Tamyis, 2020). Munculnya rasa aman semu yang berujung pada meningkatnya perilaku berisiko dan tak konsistennya adaptasi masyarakat dengan protokol kesehatan menunjukkan adanya permasalahan pada strategi komunikasi risiko selama pandemi Covid-19. Untuk memperkecil risiko penularan Covid-19 dan mengurangi rasa aman 
semu, serta membangun perilaku adaptif masyarakat yang berkelanjutan dan konsisten (Fillaili dan Tamyis, 2020).

Dampak Covid-19 menyebabkan masyarakat menjadi resah karena aktivitas ekonomi dan aktivitas sosial menjadi terhambat. Berkurangnya aktivitas masyarakat membuat ujian yang cukup berat bagi kegiatan ekonomi. Keresahan yang dirasakan masyarakat sangat beragam mulai dari ketakutan untuk bertatap muka, berkomunikasi langsung dan bersentuhan. Langkah-langkah pembatasan aktivitas melalui sejumlah aturan yang diambil pemerintah sejatinya dimaksudkan untuk menekan penyebaran wabah Covid-19 dinilai kurang efektif. Namun disisi lain, akibat pembatasan aktivitas tersebut secara tidak langsung membuat aktivitas masyarakat di tempat umum, tempat perbelanjaan, destinasi wisata dan perkantoran berkurang secara signifikan.

Kabupaten Indragiri Hilir merupakan salah satu dari 12 Kabupaten/Kota di Provinsi Riau yang ditemukan kasus terkonfirmasi positif Covid-19, berdasarkan data dari situs resmi terkait Covid-19 Pemerintah Kabupaten Indragiri hilir adalah daerah yang terpapar covid-19 dengan peringkat ke 4 paling tinggi pertanggal 5 April 2021 (corona.riau.go.id). Selanjutnya data sebaran Covid-19 di Kabupaten Indragiri Hilir dapat dilihat pada gambar berikut ini.

\section{Gambar 1. Data Sebaran COVID-19 Indragiri Hilir Pertanggal 5 April 2021}

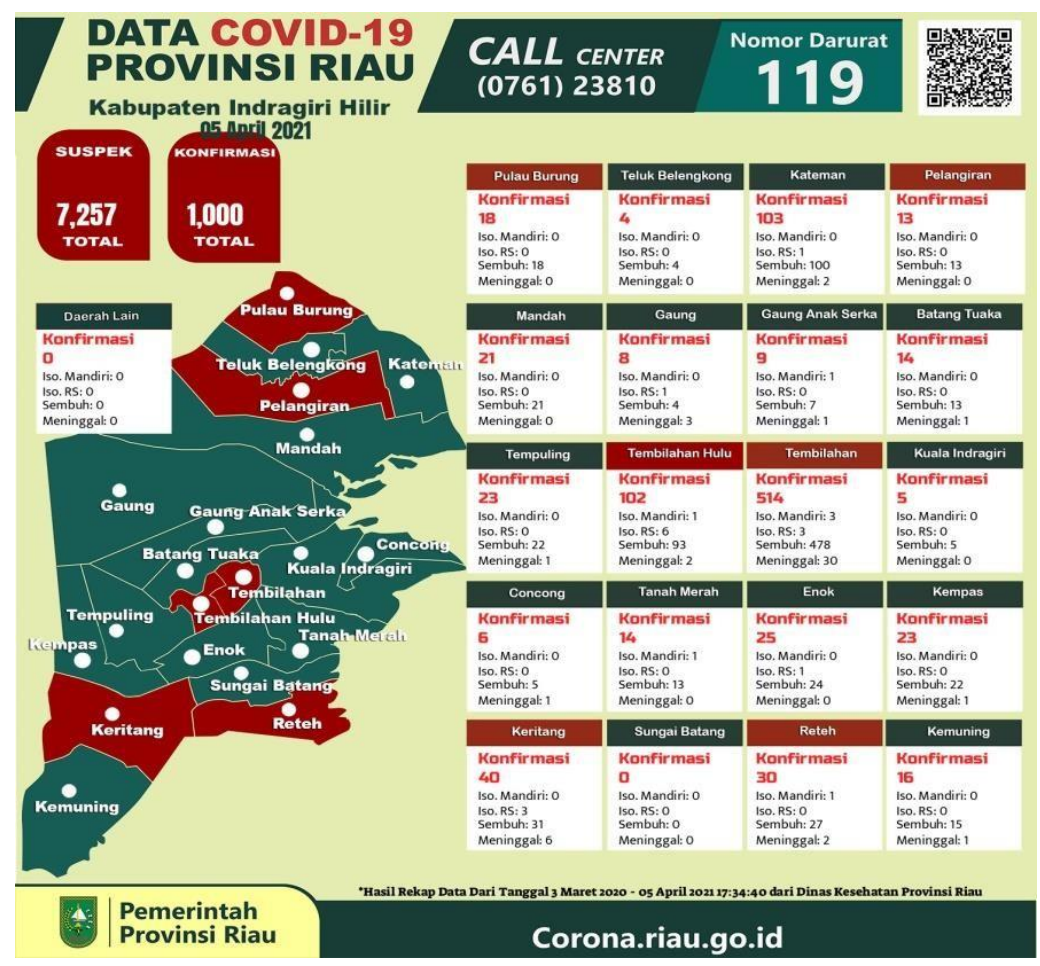

Sumber : corona.riau.go.id/inhil/ (05 April 2021)

Berdasarkan gambar 1 di atas, menunjukkan bahwa di Kabupaten Indragiri Hilir jumlah pasien suspek mencapai 7.257 orang, dengan terkonfirmasi 1000 orang, sedangkan jumlah yang sembuh 915 orang. Berdasarkan data tersebut juga dapat dilihat bahwa 
Kecamatan Tembilahan sebagai Ibukota Kabupaten Indragiri Hilir menempati urutan pertama terbesar jumlah terkonfirmasi Covid-19 514 orang, adapun yang sembuh sebanyak 478 orang, sedangkan jumlah yang meninggal sebanyak 30 orang. Selanjutnya urutan terbesar kedua jumlah terkonfirmasi Covid-19 ditempati Kecamatan Tembilahan Hulu, dimana jumlah terkonfirmasi sebanyak 102 orang, jumlah yang sembuh 93 orang, sedangkan jumlah yang meninggal sebanyak 2 orang.

Dari data tersebut terlihat bahwa selain di Ibukota Kabupaten, yang juga perlu mendapat perhatian khusus terkait pencegahan penyebaran Covid-19 dan garda terdepan pemerintahannya adalah pada wilayah pedesaan, sehingga peran desa perlu dioptimalkan. Berdasarkan data dari Badan Pusat Statistik, Kabupaten Indragiri Hilir mempunyai 246 desa dan kelurahan, 197 (80,08\%) diantaranya adalah desa (data.inhilkab.go.id). Jumlah desa tersebut, sehingga desa perlu diperhatikan secara khusus oleh pemerintah kabupaten dengan membangun sinergisitas dengan pemerintah desa dan kelurahan dalam pencegahan penyebaran Covid-19.

Sebagaimana diatur Undang-undang Nomor 6 Tahun 2014 Tentang Desa, pasal 4 hurup (g) yaitu, salah satu tujuan pengaturan Desa adalah meningkatkan ketahanan sosial budaya masyarakat desa guna mewujudkan masyarakat desa yang mampu memelihara kesatuan sosial sebagai bagian dari ketahanan nasiona (UU No.6 Tahun 2014)l. Sehingga desa dapat dioptimalkan untuk membuat ketahanan sosial baik dari segi pencegahan penyebaran Covid-19 maupun ketahanan ekonomi masyarakat desa dalam menghadapi pandemi ini.

Dalam upaya pencegahan dan penanggulangan dampak Covid-19 khsusnya di wilayah pedesaan, Menteri Desa, Pembangunan Daerah Tertinggal, dan Transmigrasi telah menerbitkan Surat Edaran Nomor 8 Tahun 2020 Tentang Desa Tanggap Covid-19 dan Penegasan Padat Karya Tunai Desa. Adapun Ruang lingkup Surat Edaran ini meliputi (1) Penegasan PKTD, (2) Desa Tanggap COVID-19; dan (3) Penjelasan perubahan APBDes. Untuk pencegahan penyebaran Covid-19 yang disebut dalam edaran ini adalah, desa di instruksikan untuk membentuk Relawan Desa Lawan Covid-19 yang terdiri dari semua elemen perangkat desa, tokoh masyarakat dan bermitra dengan Babinkamtibmas, Babinsa dan Pendamping Desa. Nantinya Relawan akan memiliki tugas dalam pencegahan penyebaran, penanganan terhadap warga korban Covid-19, dan melakukan koordinasi ke pemerintah daerah (SE. Menteri Desa PDTT No.8 Tahun 2020).

Penelitian ini bertujuan untuk mengetahui manajemen komunikasi bencana pemerintah desa dalam penenganan Covid-19 dengan mengambil studi kasus pada Desa Pekan Kamis Kecamatan Tembilahan Hulu Kabupaten Indragiri Hilir. Dipilinya Desa Pekan Kamis Kecamatan Tembilahan Hulu Kabupaten Indragiri Hilir ini sebagai lokasi penelitian memiliki beberapa alasan: Pertama, Desa Pekan Kamis merupakan pintu gerbang masuk Kota Tembilahan sebagai Ibu Kota Kabupaten Indragiri Hilir; Kedua, Desa Pekan Kamis sebagai akses jalan pintas menuju desa-desa tetangga seperti Desa Sungai Raya, Desa Sungai Junjangan dan Desa Tanjung Siantar Kecamatan Batanng Tuaka di Bagian Utara. Kemudian ada Desa Sialang Panjang Kecamatan Tembilahan Hulu dan Desa Kuala Sibatu Kecamatan Batang Tuaka di bagian Barat. Di bagian Selatan berbatasan dengan Desa Pulau Palas Kecamatan Tembilahan Hulu. Sedangkan di sebelah Timur berbatasan dengan Kelurahan Tembilahan Barat Kecamatan Tembilahan Hulu (Profil Desa Pekan Kamis, 2020). 


\section{Metode}

Metode yang digunakan dalam penelitian ini adalah deskriptif kualitatif. Penelitian kualitatif digunakan untuk mengembangkan teori yang sudah ada kemudian disajikan secara deskriptif dalam bentuk kalimat (Pujileksono, 2015). Teknik penentuan sampel yang digunakan oleh peneliti adalah purposive sampling, yaitu peneliti memilih informan yang benar-benar memahami mengenai proses pembentukan manajemen komunikasi dan informasi terkait Covid-19 di Desa Pekan Kamis. Teknik pengambilan data yang digunakan oleh peneliti adalah wawancara mendalam (indepth interview) dan obesrvasi . Data yang digunakan oleh peneliti merujuk pada data primer dan data sekunder. Data primer diperoleh melalui hasil dari wawancara dengan informan yang berasal dari unsur pemerintahan desa Pekan Kamis, yakni Misman, A.Md selaku Kepala Desa ex officio sebagai Ketua Tim Penanganan Pencegahan Penyebaran Covid-19, M. Aini selaku Ketua Badan Permusyawaratan Desa Pekan Kamis, serta Hendra Gunawan, SE sebagai Sekretaris Desa Pekan Kamis ex officio menjabat sebagai Kepala Sekretariat Tim Penanganan Pencegahan Penyebaran Covid-19. Sedangkan data sekunder diperoleh dari berbagai sumber, diantaranya; jurnal rujukan, buku, laporan berkala, profil desa, serta berita dari media online. Adapun jenis penelitian menggunakan studi kasus. Studi kasus secara sederhana diartikan sebagai proses penyelidikan atau pemeriksaan secara mendalam, terperinci, dan detail pada suatu peristiwa tertentu atau khusus yang terjadi. Studi kasus dapat diperoleh dari metode-metode penelitian formal.Sedangkan bentuk penelitian ini adalah penelitian lapangan (field research).

\section{Hasil dan Pembahasan}

Pandemi Covid-19 yang melanda dunia hingga saat ini, memberikan pelajaran tentang pentingnya manajemen komunikasi bencana. Pada level pemerintahan desa, secara kelembagaan Tim Penanganan Pencegahan Penyebaran Covid-19 sebagaimana tertuang dalam amanat Surat Edaran Menteri Desa Pembangunan Daerah Tertinggal dan Transmigrasi Nomor 8/2020 tentang Desa Tanggap Covid-19 dan Penegasan Padat karya Tunai Desa (SE.Menteri Desa PDTT No.8 Tahun 2020), merupakan lembaga yang menjadi komando utama penanggulangan bencana di tingkat desa. Pada kenyataannya berbagai problematika masih muncul dalam penanganan bencana, utamanya persoalan komunikasi, informasi, koordinasi dan kerjasama. Dalam manajemen bencana diperlukan pendekatan yang tepat yaitu pendekatan sistem, yang akan membantu dari proses mitigasi sampai pasca bencana dapat berjalan dengan baik, karena dilaksanakan secara terintergrasi dan sinergis antar lembaga dan komponen masyarakat.

Upaya penanggulangan bencana haruslah dimulai jauh sebelum bencana terjadi karena antisipasi sedini mungkin akan mampu menekan jumlah korban jiwa dan materi. Selain itu juga diharapkan muncul sikap, tindakan, dan perilaku yang menekankan kesadaran manusia dan peningkatan kemampuan manusia menghadapi ancaman.

Memaksimalkan penanganan bencana tentu melibatkan stakeholder terkait. Masingmasing memiliki tugas, sumberdaya, keterampilan, misi sampai kepentingan yang sama dan berbeda. Berbagai keluhan atau kritik atas fenomena penangan terhadap suatu peristiwa bencana merupakan pelajaran yang penting dalam manajemen bencana. Sebagaimana yang 
digambarkan dalam model alternatif manajemen komunikasi bencana di bawah ini yang meliputi aspek perencanaan, pengorganisasian, pelaksanaan dan evaluasi.

\section{Gambar 2. Model Alternatif Manajemen Komunikasi Bencana}

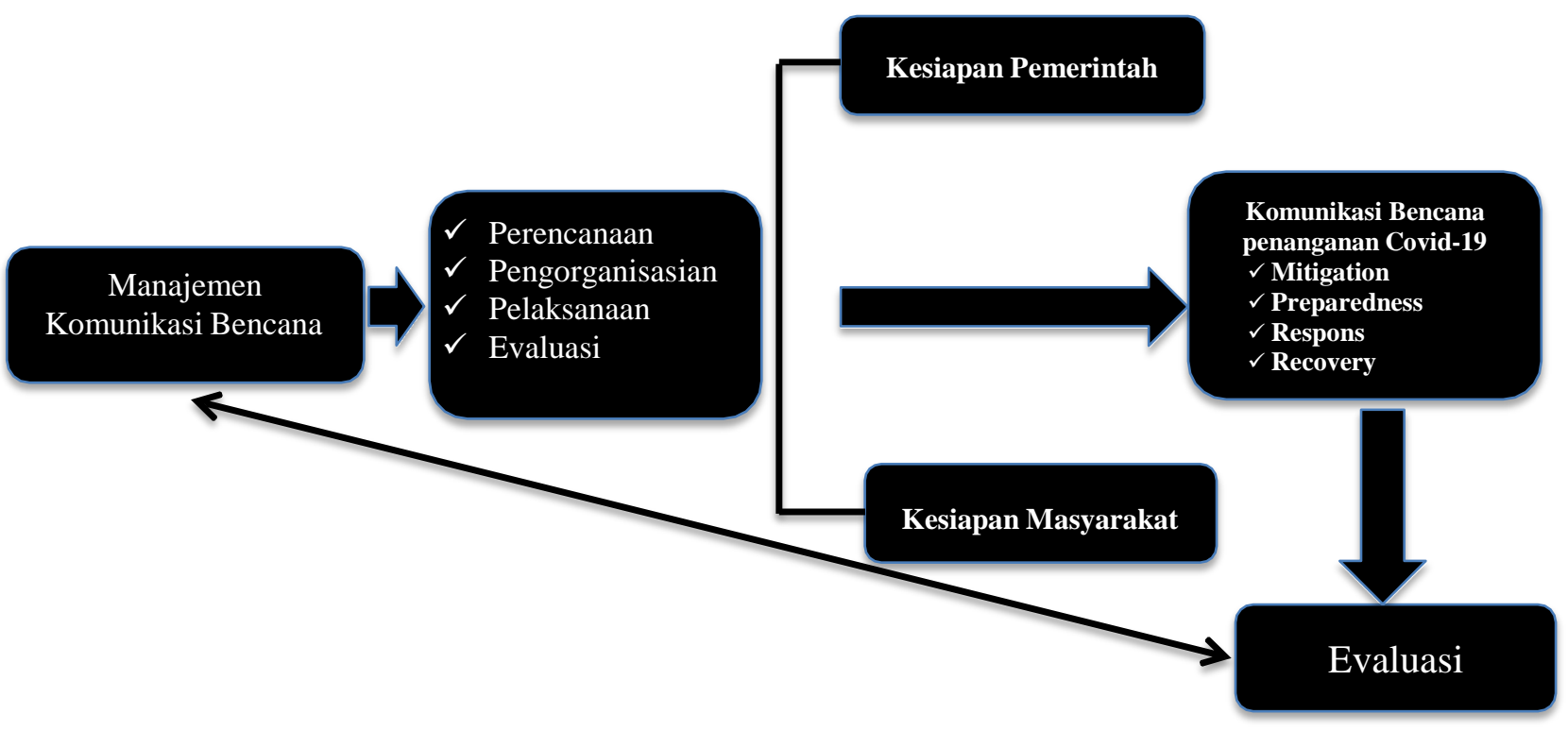

Sumber : Lestari, dkk (2013, h.155)

Merujuk pada gambar 1 model alternatif manajemen komunikasi bencana di atas, selanjutnya peneliti akan menganalisis manajemen komunikasi becana Pemerintah Desa Pekan Kamis Kecamatan Tembilahan Hulu Kabupaten Indragir Hilir dalam penanganan Covid-19 yang meliputi aspek; perencanaan, pengorganisasian, pelaksanaan dan evaluasi.

Pertama, Perencanaan Manajemen Komunikasi Bencana. Perencanaan pada dasarnya dilakukan jauh sebelum suatu kegiatan berlangsung. Perencanaan dibuat untuk dapat mengoptimalkan pencapaian tujuan yang diharapkan. Perencanaan menjadi bagian penting dalam pelaksanaan manajemen komunikasi bencana (Lestari, dkk, 2013)..

Dalam kasus penanganan pandemi Covid-19, perencanaan dibuat sebagai dasar atau pedoman dalam melaksanakan manajemen komunikasi bencana. Berdasarkan temuan peneliti di lapangan, pelaksanaan manajemen komunikasi bencana non-alam pada wabah Covid-19 pada mulanya tidak didahului dengan perencanaan. Hal ini dapat dimaklumi karena wabah Covid-19 tidak terprediksi sebelumnya. Bencana yang terjadi secara tiba-tiba mewabah ke seluruh dunia hingga ke wilayah Indonesia. Hal yang membuat masyarakat panik adanya informasi yang simpangsiur terkait wabah Covid-19 ini, termasuk di Desa Pekan Kamis. Pihak pemerintah desa mendorong untuk segera mengambil tindakan cepat saat peristiwa terjadi tanpa ada perencanaan terdahulu. Tindakan cepat yang dilakukan pemerintah desa tersebut menunggu arahan baik dari pemerintah mulai dari tingkat kecamatan, kota/kabupaten, Provinsi hingga Pemerintah Pusat.

Dalam perencanaan manajemen komunikasi bencana, sebagaimna informan 1 (Kepala Misman, A.Md Desa Pekan Kamis) memberikan penjelasan:

"semua kita sadar bahwa baru kali ini kita menghadapi wabah seperti ini. Berbeda dengan dengan bencana alam, ada gejala awalnya secara fisik yang bisa kita deteksi 
sejak awal. Tapi ini kan virus sesuatu yang tidak terlihat dan masih samar-samar gejalanya flu atau batuk sedikit langsung dituding korona dan ini blunder di masyarakat saling curiga-mencurigai. Awalnya sih kita bingung mau ngapain, yang dapat kita lalukan diawal hanya menunggu petunjuk dari atasan kita baik dari pak Camat, Pak Bupati atau dari Pak Presiden. Barulah ketika ada titik terang dan ada petunjuk melalu berbai regulasi baik itu Undang-Undang, Perpres, Surat Edaran Menteri, Bupati danlain-lainya kita bisa mengambil tindakan. Sebagai upaya Pemerintah Desa dalam menangani dampak dan pencegahan wabah Covid-19 ini, kita sudah bentuk Tim Relawan Covid-19 dimana dalam petunjuknya saya sebagai Kepala Desa langsung menjabat sebagai ketua Timnya. Kerja tim ini aktif melakukan himbauan kepada masyarakat baik himbauan langsung di tempat-tempat umum dan keramaian maupun di masjid dan mushollah. Selain itu kita juga menyiapkan himbauan berupa selebaran dan leaflet yang kita pasang ditempat-tempat umum" (Informan1)

Manajemen informasi yang dilakukan oleh Tim Penanganan Pencegahan Penyebaran Covid-19 Desa Pekan Kamis dalam memproduksi informasi juga harus tertata dengan tepat. Sebab hal tersebut tidak hanya sekedar tugas menyuguhkan informasi kepada masyarakat tapi juga memberikan rekomendasi kepada mereka atau instansi lain yang terlibat dalam penanganan Covid-19. Namun lebih daripada itu Tim Penanganan Pencegahan Penyebaran Covid-19 memiliki tugas khusus dalam melawan isu hoax, khususnya terkait informasi Covid-19. Sebagaiamana kutipan wawancara peneliti bersama informan 2 (M. Aini sebagai Ketua Badan Permusyawaratan Desa Pekan Kamis)

"Menurut saya perencanaan komunikasi terkait Covid-19 ditengah situasi
kebingunan masyarakat seperti ini sangat penting, Tapi Covid-19 ini kan awalnya
sangat mesterius sehingga kita ikut pusing dibuatnya tiba-tiba semua tidak boleh, ke
masjid tidak boleh, hajatan tidak boleh, anak-nak disuruh belajar di rumah. Pandemi
ini baru pengalaman pertama kita mengalami seperti ini, berbeda dengan kasus
demam berdarah di musim hujan atau wabah kolera dimusim kemarau kita sudah bisa
perkirakan termasuk langka menghadapinya, sedangkan Covid kan tidak ada
pengalaman kita sebelumnya. Namun seiring dengan berjalannya waktu ahirnya kita
bisa menyusun langkah-langkah perencanaan dalam upanya penanganannya.
Sehingga menurut saya memang membutuhkan satu komando informasi terkait
bencana ini. Belum lagi berita-berita yang tiap saat kita lihat melalui media online
dan media sosial, sehingga membuat masyarakat kita semakin bingung dan panik.
Untuk mengatasi virus korona ini berbagai langkah sudah kita ambil seperti
pembentukan Tim Relawan Covid, tim ini" (Informan2)

Berdasarkan hasil wawancara tersebut dapat dijelaskan bahwa perencanaan komunikasi bencana dalam penanganan Covid-19 tidak direncanakan sejak dini. Hal ini disebabkan karena wabah Covid-19 ini belum pernah terjadi sebelumnya. Berbeda dengan pandemi kesehatan lainnya seperti kolera dan demam berdarah bisa dideteksi sejak dini gejalanya. Namun seiring dengan berjalannya waktu dan berdasarkan petunjuk dari pemerintah daerah dan pusat pemerintah desa Pekan Kamis dapat menyusun langkah-langkah perencanaan dalam pencegahan dan penanggulangan dampak Covid-19. 
Kedua, Pengorganisasian Manajemen Komunikasi. Pengorganisasian dalam manajemen komunikasi bencana erat kaitannya dengan pembentukan tim yang terdiri dari pihak-pihak yang memiliki tugas dan fungsi serta bertanggungjawab dalam pengelolaan bencana yang terjadi. Pengorganisasian melibatkan berbagai pihak dengan pemilihan yang tepat (Lestari, dkk, 2013).

Di Desa Pekan Kamis, pengorganisasian manjemen komunikasi bencana dalam penanganan bencana tertuang dalam Keputusan Kepala Desa Pekan Kamis Nomor: Kpts.17/DPK/III/2020 tentang Penetapan Tim Penanganan Pencegahan Penyebaran Covid-19. Dalam Surat Keputusan Kepala Desa tersebut, jabatan ketua Tim ex officio dijabat oleh kepala desa dengan dibantu unsur perangkat desa, tokoh masyarakat, tokoh agama, pendamping desa dan unsur masyarakat lainnya.

Tugas relawan desa melawan Covid-19 sebagaimana diatur dalam Surat Edaran Menteri Desa PDTT Nomor 8 tahun 2020, meliputi; 1) Melakukan edukasi melalui sosialisasi yang tepat dengan menjelaskan perihal informasi terkait dengan Covid-19, baik gejala, cara penularan, maupun langkah-langkah pencegahannya. 2) Mendata penduduk rentan sakit, seperti orang tua, balita, serta orang memiliki penyakit menahun, penyakit tetap dan penyakit kronis lainnya. 3) Mengidentifikasi fasilitas-fasilitas desa yang bisa dijadikan sebagai ruang isolasi. 4) Melakukan penyemprotan disinfektan dan menyediakan cairan pembersih tangan (hand sanitizer) di tempat umum seperti balai desa. 5) Menyediakan alat perlindungan, serta penularan Covid-19 untuk deteksi penyebaran wabah sejak dini, dan 6) Menyediakan informasi penting terkait dengan penanganan Covid-19, seperti nomor telepon rumah sakit rujukan, nomor telepon ambulan, dan lain-lain. 7) Melakukan deteksi dini penyebaran Covid19, dengan memantau pergerakan masyarakat melalui pencatatan tamu yang masuk ke desa serta pencatatan keluar masuknya warga desa setempat ke daerah lain (SE. Menteri Desa PDTT Nomor 8 Tahun 2020).

Dalam pengorganisasian manajemen komunikasi tekait informasi Covid-19. Sekretaris Desa Pekan Kamis sebagai informan 3 memberikan penjelasan bahwa Tim Penanganan Pencegahan Penyebaran Covid-19 harus memiliki sekretariat dan media komunikasi. Hal ini agar kegiatan dan manajemen informasi dapat lebih tertata. Sebagaimana petikan wawancara berikut ini:

"Sebagai respon Pemerintah Desa Pekan Kamis dalam upaya penanganan dan pencegahan wabah Covid-19 ini, kita telah membentuk Tim Relawan Covid-19 sebagaimana perintah dalam surat Edaran Pak Menteri Desa dan juga himbauan dari pak Bupati Indragiri Hilir. Relawan ini diketuai langsung oleh Bapak Misman selaku Kepala Desa, kemudian dibantu unsur perangkat desa, tokoh masyarakat, para pendamping desa serta pihak keamanan seperti babinsa dan babinkantibmas, semuanya masuk dalam tim tersebut. Untuk memudahkan koordinasi Tim relawan difasilitasi posko penanganan Covid-19. Selain itu juga sebagai media komunikasi kita dalam Relawan tanggap Covid ini juga dibentuk WhatsApp Group dimana didalamnya semua unsur relawan tergabung, di WAG inilah kita aktif memberikan informasi terkait Covid-19 ini"'(Informan 3)

Pembentukan Tim Penanganan Pencegahan Penyebaran Covid-19 dilakukan dengan cepat oleh Pemerintah Desa Pekan Kamis setelah mendapat surat edaran dari kementerian terkait. Kepala Desa ditetapkan sebagai penanggungjawab tim yang diharapkan dapat 
melakukan penanganan pencegahan penyebaran Covid-19 dengan maksimal. Melaksanakan proses tanggap darurat dengan efektif sesuai dengan tugas dan tanggung jawab masingmasing pihak yang terlibat dalam Tim Penanganan Pencegahan Penyebaran Covid-19. Pelaksanaan tugas dan tanggungjawab seluruh tim penanganan pencegahan penyebaran Covid-19 memiliki sistem manajemen rencana di dalamnya. Pemberitahuan tambahan tugas atau informasi lain disampaikan oleh Bupati Indragiri Hilir melalui Satgas Penggulangan Covid-19 Tingkat Kabupaten, Camat Tembilahan Hulu.

Ketiga, Pelaksanaan Manajemen Komunikasi Bencana. Seluruh pelaksanaan dalam manajemen komunikasi bencana Covid-19 dilakukan berdasarkan pembagian tugas, fungsi dan tanggungjawab dari pihak-pihak yang terlibat dalam tim penanganan pencegahan penyebaran Covid-19. Pelaksanaan yang berpedoman pada peran fungsinya diharapkan dapat mempercepat proses pencapaian tujuan dan menghindari resiko yang muncul. Sebagai upaya pemenuhan kebutuhan para warga yang terdampak akibat kebijakan penanggulangan Covid19, tim penanganan pencegahan penyebaran Covid-19 sesuai dengan Keputusan Kepala Desa Pekan Kamis Nomor: Kpts.17/DPK/III/2020 tentang Penetapan Tim Penanganan Pencegahan Penyebaran Covid-19. Sebagaimana kutipan wawancara peneliti bersama Sekretaris Desa Pekan Kamis selaku informan 3 berikut ini:

"Seperti semua kita rasakan bahwa akibat wabah Covid-19 ini telah memberikan dampak yang besar bagi kehidupan masyarakat, baik itu dampak ekonomi maupun sosial. Tentu kita tidak bisa berpangku tangan melihat kondisi ini, Karena kalau ini dibiarkan ditakutkan akan terjadi gejolak di masyarakat. Kebijakan PSBB yang menghimbau masyarakat agar bekerja di rumah, beribadah di rumah dan anak-anak sekolah secara online dari rumah. Dalam merespon hal ini kita telah melalukan perubahan APBDesa, dimana refocusing anggaran khsususnya yang bersumber dari Dana Desa untuk penanganan Covid-19 ini, seperti menganggarkan Bantuan Langsung Tunai bagi warga masyarakat yang terdampak, pengadaan sarana dan prasarana pencegahan Covid-19 seperti pengadaan masker, penyemprotan disinpectant, pengadaan hand sanitizer. Diluar APBDEsa juga terdapat Bantuan Sosial Tunai dan Bantuan Pangan dari Dinas Sosial, dan dari Pemda Inhil juga ada berupa bantuan sembako kepada warga yang terdampak. Datanya bisa kami berikan nanti " (Informan 3)

Dalam rangka mengantisipasi gejolak sosial akibat adanya pembatasan kegiatan sosial masyarakat, berbagai bentuk stimulus yang diberikan baik oleh pemerintah pusat, pemerintah kabupaten maupun yang dianggarkan langsung dari APBDesa Pekan Kamis melalui program jaring pengaman sosial. Hal ini sebagaimana diutarakan oleh Kepala Desa Pekan Kamis selaku informan 1:

"Sebagai solusi agar kegiatan pembatasan sosial bisa berhasil dalam upaya meredam penyebaran virus korona di desa ini, maka berbagai bentuk bantuan dan program telah kita kucurkan, ada yang bersumber dari dana pusat (seperti PKH, BPNT, BST) ada dari DD dan ADD melalui mekanisme APBDesa. Jenis-jenis bantuan tersebut ada berupa dana tunai seperti BST, BLT (khusus penangan Covid) nanun ada juga yang sifatnya regular sudah ada sebelum Covid ini ada yakni PKH. Selain itu ada juga bantuan berupa barang yakni pemberian Sembilan bahan pokk (sembako) seperti 
BPNT, Sembako ADD. Dengan adanya bantuan tersebut kita harap ikhtiar kita untuk melindungi masyarakat kita dari korona dan sekaligus menyelamatkan perekonomian masyarakat kita akibat pembatasan sosail kiranya dapat membuahkan hasi...aamiin.."

Untuk mendukung pernyataan Informan 1 dan informan 3 sebagai upaya merespon atau tanggap darurat dari upaya pencegahan wabah Covid-19 ini, selanjutnya akan disajikan data program, jenis, besaran bantuan serta sumber bantuan berupa jarring penganman sosial:

Tabel 1 Data Bantuan dan Jenis Jaring Pengaman Sosial di Desa Pekan Kamis

\begin{tabular}{|c|c|c|c|c|}
\hline No & Jenis Program & Jumlah Bantuan & $\begin{array}{l}\text { Jumlah } \\
\text { KPM }\end{array}$ & $\begin{array}{l}\text { Instansi } \\
\text { Pemberi/ } \\
\text { Sumber } \\
\text { Dana } \\
\end{array}$ \\
\hline 1 & $\begin{array}{l}\text { Program Keluarga } \\
\text { Harapan (PKH) }\end{array}$ & $\begin{array}{l}\checkmark \text { Untuk ibu hamil dan anak usia } 0-6 \\
\text { tahunRp } 250.000 \text { per bulan; } \\
\checkmark \text { Siswa SD Rp } 75.000 \text { per bulan,; } \\
\checkmark \text { Siswa SMP Rp } 125.000 \text { per bulan, dan } \\
\checkmark \text { siswa SMA Rp } 166.000 \text { per bulan. } \\
\checkmark \text { penyandang disabilitas berat dan lansia } \\
\text { (70 tahun ke atas) Rp } 200.000 \text { per } \\
\text { bulan. }\end{array}$ & 76 & $\begin{array}{l}\text { Kementian } \\
\text { Sosial(APBN) }\end{array}$ \\
\hline 2 & BLT Dana Desa & Rp. 600.000/bulan & 58 & APBDesa (DD) \\
\hline 3 & $\begin{array}{l}\text { Bantuan Sosial Tunai } \\
\text { (BST) }\end{array}$ & Rp. 600.000/bulan & 98 & $\begin{array}{l}\text { (Kementrian } \\
\text { Sosial) APBN }\end{array}$ \\
\hline 4 & \begin{tabular}{lc} 
BPNT & \multicolumn{2}{c}{ (Bantuan } \\
Pangan & Non Tunai) \\
atau & bantuan \\
Sembako &
\end{tabular} & Rp. 300.000 (Bantuan berupa Sembako) & 25 & $\begin{array}{l}\text { (Kementrian } \\
\text { Sosial) APBN }\end{array}$ \\
\hline 5 & $\begin{array}{l}\text { Sembako Alokasi } \\
\text { Dana Desa (ADD) }\end{array}$ & $\begin{array}{ll}\text { Rp. } & 200.000 \text { Bantuan berupa } \\
\text { barang (Sembako) }\end{array}$ & 109 & $\begin{array}{l}\text { APBDesa } \\
\text { (ADD) }\end{array}$ \\
\hline
\end{tabular}

Sumber : Data Olahan Peneliti, 2020

Berdsarkan tabel 1 di atas, dapat diketahui bahwa terdapat 5 jenis program bantuan berupa program Jaring Penagaman Sosial (JPS) dalam penanggulanagan dampak wabah Covid-19, kelima program dimaksud adalah; Program Keluarga Harapan (PKH), Bantuan Langsung Tunai Dana Desa (BLT-DD) dengan besaran bantuan Rp.600.000 per KPM (Keluarga Penerima Manfaat), Bantuan Sosial Tunai (BST) dengan besaran bantuan Rp.600.000 per KPM, Bantuan Pangan Nontunai (BPNT) senilai Rp. 300.000,- Per KPM dalam bentuk sembako dan Bantuan Sembilan Bahan Pokok Alokasi Dana Desa (Sembako ADD) senilai Rp.200.000,- per KPM. Dari lima program JPS tersebut Program Keluarga Harapan (PKH) merupakan program lanjutan dan sudah ada sebelum adanya pandemi Covid19, sementara keempat program JPS lainnya; Bantuan Langsung Tunai Dana Desa (BLT- 
DD), Bantuan Sosial Tunai (BST), Bantuan Pangan Nontunai (BPNT) dan Bantuan Sembilan Bahan Pokok Alokasi Dana Desa (Sembako ADD) merupakan program JPS yang hadir setelah pandemi Covid-19.

Keempat, Evaluasi Manajemen Komunikasi Bencana. Evaluasi yang dilakukan dalam hal ini adalah terhadap manajemen komunikasi bencana dalam tanggap darurat pada bencana Covid-19. Berdasarkan temuan peneliti di lapangan menemukan ada evaluasi yang dilakukan pihak terkait yakni Pemerintah Desa Pekan Kamis bersama Tim Relawan Covid-19 terhadap manajemen komunikasi bencana yang dilakukan.

Evaluasi yang dilakukan meliputi pelaksanaan suatu kebijakan maupun kegiatan yang telah diprogramkan atau dilakukan dan dibahas dalam rapat bersama pihak tim penanggulangan bencana yang sudah dibentuk. Evaluasi yang dilakukan bisa sifatnya mingguan dan bulanan.. Evaluasi dilakukan dengan melibatkan seluruh pihak yang ada dalam tim untuk mengetahui progres atas kegiatan yang dilaksanakan dan mengetahui kekurangan sebagai bahan untuk dapat diperbaiki agar bisa lebih baik pada masa yang akan datang, sebagaimana kutipan wawancara peneliti bersama informan 2 (Ketua Badan Permusayaratan Desa (BPD) sebagai berikut:

"dalam melaksanaan evaluasi terkait kebijakan dan manajemen komunikasi yang sudah kita tetapkan bersama dalam upaya menanggulangi dampak dan pencegahan wabah Covid-19 ini, kita rutin melakukan rapat Tim Relawan Covid baik sifatnya mingguan bulanan atau bahkan rapatnya bisa mendadak jika ada hal-hal yang penting untuk kita putuskan. Biasanya yang paling sering jadi masalah adalah soal Data KPM penerima bantuan, karena terlalu banyak jenis bantuan ada yang permanen dan ada yang tentatif, ada yang langsung dari APBDesa seperti BLT DD, dan nada yang langsung dari pusat (Kementrian Sosial) biasanya ini yang sering jadi masalah, namun berkat koordinasi dan komunikasi Alhamdulillah bisa kita atasi bersama. Intinya menurut kami kebersamaan, apapun jadi ringan kalau beban samasama kita pikul bersama" (Informan 2).

Hal senada juga diutarakan oleh Informan 1 (Kepala Desa Pekankamis), sebagaimana petikan wawancara berikut ini:

"Mendapat amanah sebagai kepala desa yang tugas pokoknya melayani dan mensejahterakan masyarakatnya itu bukan pekejaan ringan, terasa bebannya double dikala pandemi Covid-19 ini hadir, apalagi jabatan ketua secara otomatis djabat oleh kepala desa. Alhamdulillah berkat kerjasama semua pihak, para perangkat desa, BPD, Mitra Desa seperti para pendamping desa untuk semua program pemberdayaan, Babinsa dan Babinkantibmas, tokoh agama, tokoh masyarakat, kalangan pemuda dan umumnya dukungan masyarakat Desa pecan Kamis Alhamdulillah hingga saat ini semua dapat kita lalui dengan baik. Begitu juga terkait Covid ini, meskipun ada masyarakat yang dalam kategori ODP, namun hasilnya semunya negatif. Kita berharaf semua pihak jangan lengah, karena pandemic ini masih mewabah, maka harapan saya agar protocol kesehatan senantiasa dipatuhi oleh masyarakat kai " (Informan 2).

Berdasarkan petikan wawancara dengan informan 2 di atas, pada dasarnya komunikasi 
memiliki sejumlah pengaruh baik pada jenis, tujuan, tugas pemerintahan termasuk pemeliharaan hubungan. Dengan tidak adanya fasilitas untuk hubungan komunikasi ke semua arah dan stakeholders yang ada di desa dalam sebuah kegiatan, akan sulit untuk mengetahui apa yang telah dicapai, apa yang akan dicapai dan bagaimana hambatan dalam pelaksanaan kerja dan komunikasi merupakan sumber informasi bagi para pemimpin dalam menginformasikan berbagai kebijakan atau penanganan untuk melawan Covid-19 di Desa Pekan Kamis.

Manajemen Komunikasi Bencana yang dilakukan pemerintah Desa Pekan Kamis di atas tujuannya adalah sebagai salah satu strategi bertujuan untuk mencegah penyebaran penyakit kedaruratan kesehatan masyarakat dan memutus mata rantai penyebaran Covid-19 yang sedang terjadi saat ini.

Manajemen komunikasi bencana adalah seluruh kegiatan yang meliputi aspek perencanaan dan penanggulangan bencana pada, sebelum, saat, dan sesudah terjadi bencana yang dirancang untuk memberikan kerangka kerja bagi orang-perorangan atau komunitas yang berisiko terkena bencana untuk menghindari, mengendalikan risiko, mengurangi, menanggulangi maupun memulihkan diri dari dampak bencana

Manajemen komunikasi bencana melibatkan perencanaan, pengorganisasian atau koordinasi, pelaksanaan, dan evaluasi. Keterlibatan dan koordinasi antar pihak pemerintah, stakeholders dan relawan dalam manajemen komunikasi bencana sangat dibutuhkan guna membangun suatu komunikasi bencana yang dapat dipahami makna pesannya sehingga menghasilkan umpan balik yang diharapkan berdasarkan tujuan pesan yang disampaikan.. Kajian mengenai manajemen bencana digunakan untuk dapat mengamati serta mencermati praktek manajemen bencana yang diterapkan dalam suatu peristiwa bencana yang terjadi pada bencana non alam berupa Covid-19. Melalui kajian ini dapat dilihat pemahaman dan pengetahuan para pihak terkait penanganan bencana yang terjadi dan dapat ditemukan kendala dan solusi yang tepat dalam menerapkan manajemen bencana yang efektif.

\section{Simpulan}

Berdasarkan hasil pembahasan yang telah dipaparkan di atas, manajemen komunikasi bencana dapat menjadi solusi atau strategi yang tepat dalam upaya penanganan sebuah bencana kesehatan seperti pandemi Covid-19. Beberapa catatan penting dalam simpulan penelitian ini sebagai berikut: (1) Bahwa semua pihak harus saling terlibat dan bekerjasama dalam upaya penanggulangan bencana Covid-19. Pemerintah desa harus mampu memetakan ancaman bencana yang ada di sekitar daerahnya. Menentukan strategi, dan pihak yang bertanggungjawab dalam pelaksanaan penanggulangan bencana yang akan dilakukan. (2) Pihak pemerintah desa atau tim yang dibentuk harus mampu menyadarkan dan mendidik warganya akan bahaya bencana. Penyadaran dan pendidikan terhadap warga ini dapat dilakukan dengan komunikasi dan sosialisasi mitigasi bencana. Masyarakat yang paham tentang mitigasi bencana yang ada di sekitarnya akan saling bekerjasama dengan pemerintah dan warga lainnya mematuhi SOP (Standard Pelayanan Prosedur) penanganan bencana seperti dalam kasus pandemi Covid-19. Seperti mematuhi protokol kesatan. (3) Pihak pemerintah desa atau tim yang dibentuk bersama warga masyarakat saling bekerjasama menentukan kebutuhan yang diperlukan warga. Hal ini dilakukan agar saat bencana datang tidak menimbulkan kekacauan dalam membagikan kebutuhan bagi warga. Kebutuhan tersebut tidak 
hanya dalam bentuk makanan, tetapi juga sandang, papan, dan obat-obatan, serta kebutuhan psikologis, dan lain sebagainya. (4) Pemerintah membuat sebuah rencana kontijensi setiap ancaman bahaya yang ada. Hal ini merupakan sebuah kunci sukses dalam penanggulangan bencana. Dalam rencana kontijensi ditetapkan pihak yang bertanggungjawab ketika bencana datang, Strategi, jalur evakuasi, sarana dan prasarana yang dibutuhkan dan bahkan dalam beberapa rencana kontijensi telah ditetapkan perkiraan waktu bencana terjadi serta penanggulangan dalam bencana tersebut. (5) Diharapkan dengan adanya persiapan yang matang baik dari pihak pemerintah desa dan warga masyarakat, dapat menciptakan manajemen komunikasi bencana yang efektif sehingga resiko bencana yang mungkin muncul dapat dikurangi bahkan dihindari. Dengan demikian diharapkan dapat terbangun manajemen komunikasi bencana yang melibatkan komunikator, komunikan, pesan serta umpan balik yang efektif antarpihak yang terlibat sehingga dapat tercipta kesamaan makna pesan dalam proses manajemen komunikasi bencana yang berlangsung.

\section{Referensi}

Bencana, ASPIKOM, Mata Padi Pressindo, Jakarta , (2011), Komunikasi Bencana, Yogyakarta: Mata Padi Pressindo

Desa.(2020). Profil Desa Pekan Kamis Kecamatan Tembilahan Hulu Kabupaten Indragiri Hilir Tahun 2020.

Kementerian Luar Negeri. (2020). Virus-Corona-Atau-Severe-Acute-Respiratory-SyndromeCoronavirus-2-Sars-Cov-2.https://kemlu.go.id/kabul/id/news/5980/virus-corona-atausevere-acute-respiratory-syndrome-coronavirus-2-sars-cov-2.

Fillaili, R., Tamyis AR. (2021) Menjaga Persepsi Risiko Masyarakat Melalui Komunikasi Risiko Yang Efektif Pada Masa Pandemi Covid-19, https://smeru.or.id/id/content/menjaga-persepsi-risiko-masyarakat-melalui-komunikasirisiko-yang-efektif-pada-masa-pandemi, catatan kebijakan Smeru Nomor 7/Des/2020

Gunung Sinabung 2010 Saat Tanggap darurat. Jurnal Ilmu Komunikasi Volume 10 Nomor 2, Desember 2013. Prodi Ilmu Komunikasi FISIP UPN “Veteran”. Yogyakarta.

Kepala Desa. (2020). Keputusan Kepala Desa Pekan Kamis Nomor: Kpts.17/DPK/III/2020 tentang Penetapan Tim Penanganan Pencegahan Penyebaran Covid-19.

Kementerian Desa. (2020). Peraturan Menteri Desa, Pembangunan Daerah Tertinggal, dan Transmigrasi tentang Perubahan atas Peraturan Menteri Desa, Pembangunan Daerah Tertinggal, dan Transmigrasi Nomor 11 Tahun 2019 Tentang Prioritas Penggunaan Dana Desa Tahun 2020. ttps://peraturan.bpk.go.id/Home/Details/139739/permendespdtt-no-6-tahun-2020

. (2020). Surat Edaran Menteri Desa Pembangunan Daerah Tertinggal dan Transmigrasi Nomor 8/2020 tentang Desa Tanggap Covid-19 dan Penegasan Padat karya Tunai Desa.

Lestari, P,. Agung, P,. (2013). Manajemen Komunikasi Bencana Pranita, E. (2002). Diumumkan Awal Maret, Ahli: Virus Corona Masuk Indonesia dari Januari. Kompas.com. $\quad$ https://www.kompas.com/sains/read/2020/05/11 /130600623/diumumkan-awal-maret-ahli--virus- corona-masuk-indonesia-dari-januari.

Pujileksono, S,. (2015), Metode Penelitian Komunikasi Kualitatif. Malang: Kelompok Intrans Publishing.

Susanto, E.H,. (2011). Eksistensi Komunikasi Dalam Menghadapi Undang-Undang Nomor 6 Tahun 2014 tentang Desa

Undang-Undang Nomor 6 Tahun 2014 tentang Desa

Undang-Undang Nomor 24 Tahun 2007 tentang Penanggulangan Bencana 